\title{
Chapter 7 \\ Hotel Ships on the Douro River and Their Relationship with the Terroir
}

\author{
Alexandre Guedes and Veronika Joukes
}

\begin{abstract}
This chapter focuses on how the operators of hotel ships interrelate - in their aim to seduce clients - the river and the terroir, the two defining morphologies of any visit to the Douro Valley, an excellent wine region crossing the North of Portugal from Oporto and Vila Nova da Gaia on the Atlantic coast to the frontier with Spain, near Salamanca. Starting from a portrait of the navigability of the river and the tourism accommodation on land, we provide preliminary data from an ongoing study that analyses how hotel ship operators interpret and sell the Douro region. Concentrating on the online programmes provides us with the opportunity to observe the formal mechanisms with clear expertise in directing the consumer decision-making processes, in this case, of those interested in visiting the Douro Valley, as well as having an impact on its destination image. A quantitative and content analysis allows us to map the tourist operations that merge the potential of the river and that of the terroir, and then, to reflect about the selected combinations. More particularly, we aim to determine the kinds of wine tourism experiences that are being included in the Douro river cruise programmes in order to verify whether all aspects of the enotourism potential of the region have been fully realised in our sample. Finally, the chapter concludes with a list of suggestions to inspire the programme makers to enhance local development in a more equitable way, and thus, to improve the current business model.
\end{abstract}

\footnotetext{
A. Guedes

University of Trás-os-Montes and Alto Douro (UTAD) and Portucalense University (UPT),

Vila Real, Portugal

e-mail: aguedes@utad.pt; aguedes@upt.pt

V. Joukes $(\bowtie)$

Departamento de Economia, Sociologia e Gestão (DESG) of the University of Trás-os-Montes and Alto Douro (UTAD) and Centro de Estudos Transdisciplinares para o Desenvolvimento (CETRAD), Vila Real, Portugal

e-mail: veronika@utad.pt
} 


\subsection{Introduction}

This chapter focuses on the relations and the economic articulation between the hotel ships in the Douro region and the two morphologies that endorse the tourism phenomenon there, namely, the river and the surrounding land or terroir. ${ }^{1}$ Starting from a portrait of the performance of the river and the terroir, namely, of the navigability and accommodation sectors, which is based on official Portuguese quantitative data, this essay provides preliminary data from an ongoing study that analyses the programmatic scope of hotel ship operators, their relationship with the Douro region and the ways in which they intervene territorially. Our analysis of the online programmes of the hotel ships operating on the Douro allows us the opportunity to observe the formal mechanisms with clear expertise in directing the consumer decision-making processes of travellers, as well as influencing the destination image of the Douro Valley.

The analysis of these sources allows us to X-ray the tourist operations that begin with the river and to verify the degree of its interception with the terroir (the municipalities that are selected, the length of the visits and that which is done/seen on site). More particularly, we aim to determine the kinds of wine tourism experiences that are being included in the Douro river cruise programmes, such as visits to a quinta (winery)/vineyards or other wine-related activities (Adams 2006), and we also want to measure the temporal and spatial weight of these specific activities in the programmes of this vineyard territory. In other words, we plan to find out the extent to which the wine tourism potential of the region is articulated in the tours programmed by Douro operators. Finally, the chapter concludes with an exegesis of the economic opportunities that are stimulated by the river, but that can be put into practice and expanded on land, and in that way, stimulate local development of the adjacent zones, namely, those that can be reached via river docks, thus improving the potential for the sustainable growth of the wine regions in a particular context (Del Río Rama et al. 2013, 2014). This effort should benefit the current business model.

\subsection{Brief Characterization of the Douro Region}

A discussion of the Douro region in Portugal implies a knowledge of its main supporting element: the Douro River, which gives it its name, has its source in Spain in the Sierra de Urbión at 2,080 m of altitude, and flows $938 \mathrm{~km}$ downstream into the Atlantic Ocean in Portuguese territory. Not even 50 years ago, the $209 \mathrm{~km}$ length of the Douro River on the Portuguese side was transformed into a navigable

\footnotetext{
${ }^{1}$ Rastoin and Vissac-Charles (1999) define terroir as a clearly identified and homogeneous territory provided with a strong identity which is characterised by the sum of all natural and cultural resources, whereas Ditter (2005) adds that a terroir is generally backed up by a certificate of guaranteed origin label.
} 
waterway by building five dams to overcome a height difference of $132 \mathrm{~m}$, again making a solid collaboration between the river and the terroir possible.

The geometry of the region is varied and voluminous, and without doubt, the vineyard unit, demarcated and regulated in 1756 as the Demarcated Douro Region (DDR), with a corresponding area of about $250,000 \mathrm{ha}$, is the one that best expresses this character. This is the region where Port Wine is exclusively produced, although it acquired its name not from the region where it originated, but from the city that played (and still plays) a key role in its export, Oporto. It is in this territory that the Alto Douro Wine Region (ADWR) is located, which occupies 24,600 ha. This micro region is characterised by a distinctive landscape and brand, and it is internationally recognised because it was awarded with the rank of a World Heritage site in the category of a living and evolving cultural landscape by UNESCO in 2001. In other words, as can be seen in Fig. 7.1, the ADWR represents 1/10 of the area of the DDR, mostly concentrated on the river banks. Its landscape is the result of a secular vineyard pattern that has evolved over time and produces not only the well-known Port Wine, but also several quality still wines that are increasingly renowned and awarded internationally.

Until the end of the last century, the Douro has been one of the few points of access to the North of Portugal. There are documents that testify about the profound knowledge of the river that, since Roman times, has been necessary for its use to transport goods and people. The main sense of ancestral navigation has been a pendulum movement east/west, respecting the natural downstream flow of the river, carrying the region's natural resources to the port city, Oporto, to possibly enter international distribution circuits there. The rabelo, a specially designed boat, was used to defy "the river that is hard to navigate" (o rio de mau navegar); indeed, the Douro was very difficult to follow, among other things, because of the "sharp gradient,

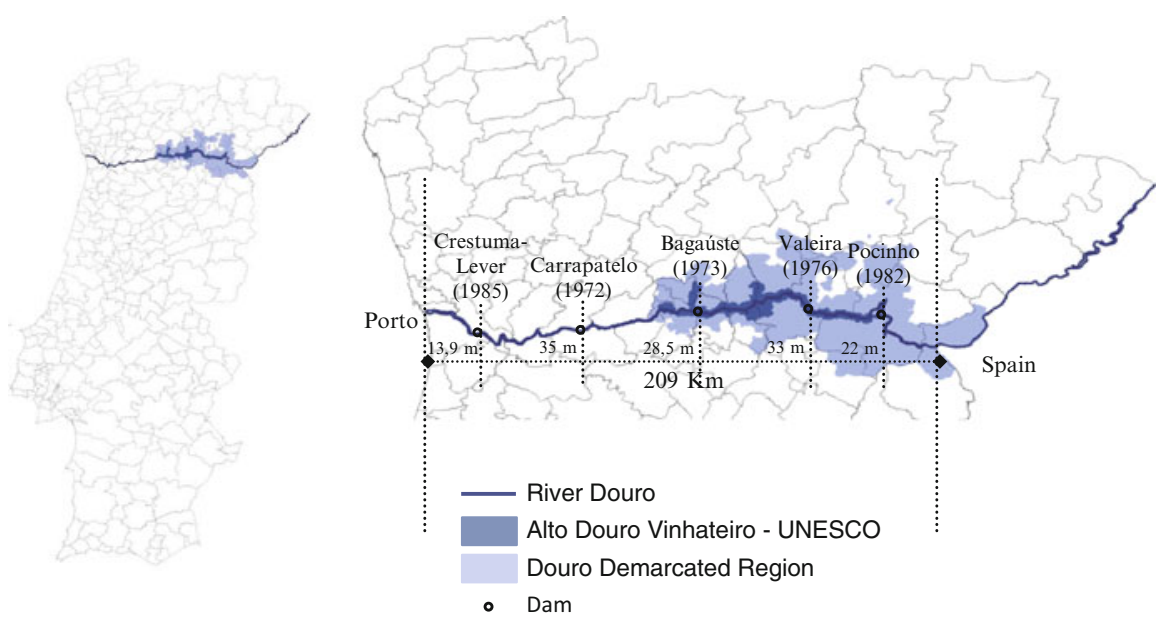

Fig. 7.1 Portugal, the Douro River, the Demarcated Douro Region and the Alto Douro Wine Region (UNESCO). Source: DGT (2014) and CNIG (2015) - map prepared by A. Guedes 
Table 7.1 Dams in the Douro River

\begin{tabular}{l|l|l}
\hline Dams in the Douro & Inauguration (year) & Height (m) \\
\hline Crestuma-Lever Dam & 1985 & 13.9 \\
\hline Carrapatelo Dam & 1972 & 35 \\
\hline Bagaúste Dam & 1973 & 28.5 \\
\hline Valeira Dam & 1976 & 33 \\
\hline Pocinho Dam & 1982 & 22 \\
\hline
\end{tabular}

Source: IPTM (2013)

tight curves, protruding rocks, violent currents, multiple irregularities, rapids and the numerous cataracts and sharp drops"(IPTM 2014). Early in the last century, for example, the $130 \mathrm{~km}$ between Tua and Oporto were traversed, on average, over two days downstream and over 5-10 days upstream. Everything depended on the navigability of the river, whose flow was higher from December to May, a period that coincided with the wine production cycle. Yet another detail reveals the degree of difficulty of this route: the wine barrels, also carried in rabelo boats, were never fully filled, so that in case of a shipwreck, something that happened far too regularly, they could float in the river and be recovered (Domingues s.d.; IPTM 2014).

With the opening of the railway line of the Douro to Pocinho in January 1887, and with the inauguration of a direct rail service from Oporto to Salamanca via Barca d'Alva in December of the same year, the rabelo boats were disappearing from the river; one record shows that, in 1961, only five of them were still transporting Port Wine between Freixo do Numão and Vila Nova de Gaia (Cardoso 1998: 118). By the end of the twentieth century, the river again assumed a leading role in matters of transport due to the completion of a sluice system, i.e. five dams and sluices were constructed along the $209 \mathrm{~km}$ through which the Douro runs in Portugal. It was an investment that quickly imbued the river with a strong economic dimension stemming from its navigability, because these infrastructures increased and stabilised the flows in the dammed reservoirs and allowed the substantial height difference $(132 \mathrm{~m})$ that characterises the Portuguese part of the river to be overcome (Fig. 7.1 and Table 7.1). In 1994, commercial navigation began: This defined and set a new pendulum movement, west/east, and facilitated the upstream transport of tourists from Oporto and Vila Nova de Gaia via the Douro/Duero, to Vega Terrón in Spain.

\subsection{Brief Portrait of the Tourism Phenomenon in the Douro Valley ${ }^{2}$}

Since the Alto Douro Wine Region was classified as a World Heritage site by UNESCO in 2001, tourism in the Douro region has gained strong political and institutional support from the Portuguese Government (Andresen and Rebelo 2013), which reveals the importance and/or tourism potential of this region. Moreover, the Douro's unique features were reaffirmed by its classification in seventh place

\footnotetext{
${ }^{2}$ This section is based on Rebelo et al. (2014).
} 
in the category of Best Rated Places by the National Geographic Society in an international ranking of 133 sites/destinations in 2009, as it is in an excellent state of conservation, relatively intact.

Tourism in the Douro is structured by two determining factors: the river and the terroir (Rebelo et al. 2013). From an economic point of view, the river, as a navigable waterway, has facilitated growth; as can be seen in Table 7.2, in 2013, this ensured work for 35 companies with 86 vessels having a total carrying capacity of 6,124 passengers. The river boat sector, however, exhibits divergent trends: The hotel ships had an occupancy rate of around $76 \%$ between 2010 and 2013, while regular boats had occupancy rates that were lower by about 31 percentage points.

Waterborne transport is a sector that has thrived consistently, with average growth rates, between 2007 and 2013, of approximately $27 \%$, with a total of 545,630 passengers in 2013, of which 39,352 (7\%) were on hotel ships and 150,034 (27.5\%) were on 1-day cruises. Cruise ships operating within the same reservoir, i.e. a river stretch between two dams or bridges, welcomed 350,275 (64\%) passengers aboard, a segment that grew about $43.9 \%$ between 2012 and 2013 (Table 7.3).

The heterogeneity of this sector is also marked by the nationality of the passengers: In the sub-sector of hotel ships, around $97 \%$ of the clients are foreigners, whereas

Table 7.2 River tourism supply indicators: 2010-2013

\begin{tabular}{l|l|l|l|l}
\hline Supply & 2010 & 2011 & 2012 & 2013 \\
\hline $\begin{array}{l}\text { Companies operating regular boats (IPTM, } \\
\text { 2011-2013) }\end{array}$ & - & 32 & 34 & 35 \\
\hline Number of regular boats (IPTM, 2010-2013) & 51 & 54 & 66 & 86 \\
\hline Number of hotel boats (IPTM, 2010-2013) & 7 & 8 & 8 & 11 \\
\hline Total boats' capacity (IPTM, 2010-2013) & 4,810 & 5,519 & 5,874 & 6,124 \\
\hline Hotel boats' occupancy rate (IPTM, 2010-2013) & $76.45 \%$ & $75.19 \%$ & $76.75 \%$ & $76.75 \%$ \\
\hline Regular boats' occupancy rate (IPTM, 2010-2013) & $52.2 \%$ & $45.24 \%$ & $42.01 \%$ & $42.01 \%$ \\
\hline
\end{tabular}

Source: IPTM (2013)

Table 7.3 Number of passengers per type of boat/trip: 2007-2013

\begin{tabular}{l|l|l|l|l|l|l|l|l}
\hline & & & & & & & & \\
Demand & 2007 & 2008 & 2009 & 2010 & 2011 & 2012 & 2013 & $\begin{array}{l}\text { Average } \\
\text { Var. 2007/ } \\
2013(\%)\end{array}$ \\
\hline $\begin{array}{l}\text { Hotel boats } \\
\text { (HB) }\end{array}$ & 17,724 & 20,982 & 19,711 & 22,017 & 26,454 & 28,089 & 39,352 & 15.08 \\
\hline $\begin{array}{l}\text { Cruises- } \\
1 \text { day }(C)\end{array}$ & 148,02 & 144,187 & 159,198 & 173,143 & 153,033 & 135,688 & 150,034 & 0.70 \\
\hline $\begin{array}{l}\text { Recreation } \\
\text { boats (RB) }\end{array}$ & 6,820 & 4,842 & 6,457 & 6,160 & 5,724 & 5,632 & 5,969 & -0.50 \\
\hline $\begin{array}{l}\text { Cruises in the } \\
\text { same reservoir } \\
\text { (CSR) }\end{array}$ & - & - & - & - & - & 243,419 & 350,275 & 43.90 \\
\hline $\begin{array}{l}\text { Total (HB +C } \\
\text { +RB + CSR })\end{array}$ & 172,560 & 170,011 & 185,366 & 201,320 & 185,211 & 412,831 & 545,630 & 27.20 \\
\hline
\end{tabular}

Source: IPTM (2013) 
the 1-day cruises depend heavily on the domestic market (94\%). The success of the hotel ships is linked to distribution mechanisms that guarantee a growing demand and reach a wide range of markets/countries, which are mainly concentrated in Europe ( $76 \%$ of the demand), but also in the USA, which generates about $21 \%$ of the demand.

The dominant tourist activities in the Douro reveal that the cultural reality immersed in this region is extensively based on wine (Rebelo et al. 2013). The transformation of several wine estates, from the 1990s onwards, elucidates this new reality, which is the fruit of radical changes: They opened their doors to the public and prepared themselves to welcome visitors. In all, there are about 25 wine farms that meet the requirements to receive tourists (ERTD 2012; Rebelo et al. 2013). Today, in the Douro region, you can do what has been typically available for decades in other parts of the world, e.g. combine sleeping in a wine estate with a visit to a winery accompanied by an expert guide who is fluent in several languages, participate in guided wine tasting sessions, help in the grape harvest, crush the grapes with your feet, and walk along marked paths at a wine property.

The official accommodation sector includes 36 hotels with an overall capacity of 2,303 beds (Table 7.4), along with a substantially higher number of rural tourism units (101) having a much smaller bed capacity (552). The hotels were responsible for generating, on average and annually between 2010 and 2012, about 8 million euro in room revenue.

Despite the classification of ADWR as a world heritage site in 2001, the number of hotels (units and beds) did not increase, as the ratio of hotels/beds in 2001 was $34 / 2,276$ and in 2012 it was almost the same, i.e. 34/2,280.

The demand shows quantitative indicators of the overnights at hotels which reveals positive development, particularly after an examination of the data published in 2013. On average, between 2001 and 2013, the number of overnight stays and the number of guests in hotels reveal positive changes in the amounts of $2.04 \%$ and $2.15 \%$, respectively. However, if we look at the average of the changes in the number of overnight stays and guests between 2001 and 2012, there was a negative development during this period of about $-1.6 \%$ and $-1.1 \%$, respectively, which shows the importance of the growth that occurred in the last statistical year with respect to these two indicators. The average stay has remained on the threshold of 1.5 nights, and the net occupancy rate of $28 \%$ in 2001 and $27.07 \%$ in 2013 reflect slow economic performance (Table 7.5).

Table 7.4 Hotel establishments and rural tourism units: 2010-2012

\begin{tabular}{l|l|l|l|l}
\hline Supply & 2010 & 2011 & 2012 & $\begin{array}{l}\text { Ratio } \\
\text { beds/units }\end{array}$ \\
\hline Number of hotel establishments & 34 & 39 & 36 & \\
\hline Number of beds in hotel establishments & 2,280 & 2,466 & 2,303 & 64 \\
\hline Number of rural tourism units (TER) & - & - & 101 & \\
\hline Number of beds in rural tourism units (TER) & - & - & 552 & 5 \\
\hline Guest room income - hotel establishments & $8,334,000$ & $8,466,806$ & $7,098,000$ & \\
\hline
\end{tabular}

Source: INE (2002-2014) and /ERTD (2012) 


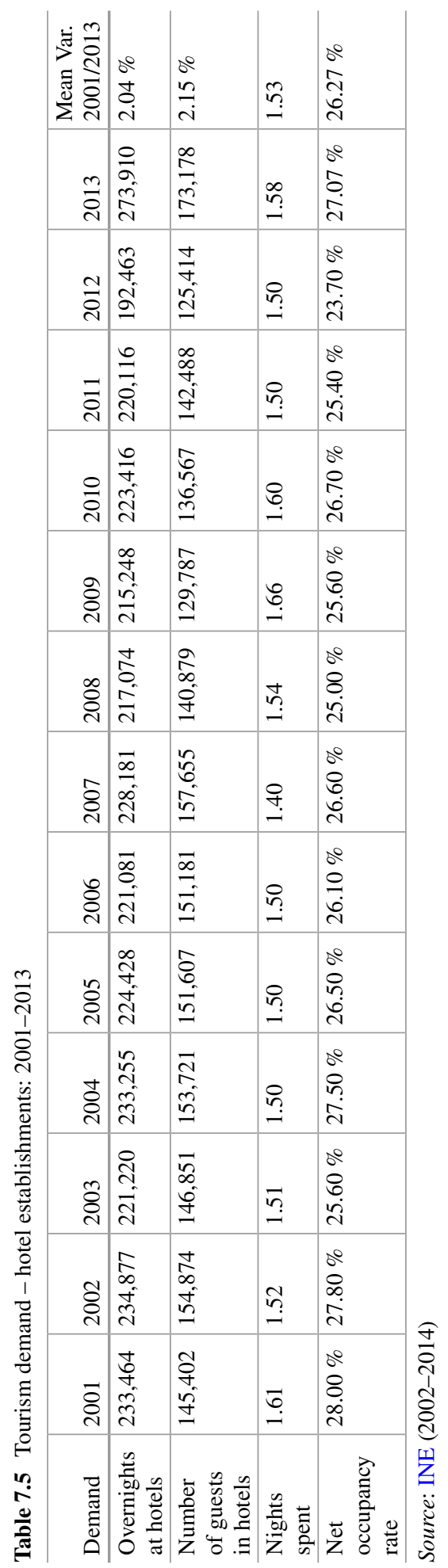


Note that the on-land accommodation sector, as opposed to the scenario of hotel ships, depends mainly on domestic market demand, which represented, on average, about $74 \%$ of the total demand (overnight stays) between 2001 and 2013 (INE 20022014), and the remaining demand is dispersed over six European markets (Great Britain, Spain, France, Germany, the Netherlands and Italy). It is precisely the internal market that affects the results: The Portuguese, severely hit by the global economic crisis, have generally chosen to travel less since 2008 (Turismo de Portugal 2009).

In summary, we conclude that the tourism phenomenon in the Douro is interlinked with two relevant spaces: the river, where nautical tourism formulas have been successfully developed, and where the hotel ship segment, in particular, has distinguished itself through a sustainable level of growth supported by a high degree of internationalisation in the markets; and the terroir, which has shown far less productive operating volumes and trends. These opposite results presuppose the need to strengthen the relationship between these two economic poles, which provide the structure for tourism in the Douro region. The sector of hotel ships appears to provide important opportunities for access to international markets; however, do their programmes efficiently integrate the supply potential that is available on land? Adapted and improved cooperation might lead to common benefits (favouring both the river and the terroir-linked stakeholders) that take into account and live up to the fact that the recognition of UNESCO was partially motivated by its conviction that the matrix and morphological value of the sum "land plus river" was more than the set of resources of each of them alone.

\subsection{Case Study: The Hotel Ships and Their Connection with the Terroir}

\subsubsection{Research Method}

The empirical analysis, for which we will present preliminary results, is the outcome of an observation exercise of online published cruise programmes focused on the Douro River from a group of eight tour operators, one based in Portugal, and the others in France, the USA, Great Britain and Belgium. The sample (non-probabilistic or nonrandom) expresses, with a high degree of accuracy, an almost complete picture of the market segment of hotel ships with programmes including at least six overnight stays on the Douro. The physical infrastructure (fleet) of this sector is owned by two maritime tourism companies, Douro Azul (Portuguese company) and CroisiEurope (French company). The business model adopted by the Portuguese company (Douro Azul) implies the "outsourcing" of the design and execution of the most diverse cruise programmes, thus involving more private companies in the business scheme and distributing the risks/responsibilities/investments. A main advantage of this practice is the internationalisation of the marketing and commercialisation of the Douro River as a navigable waterway, a process that we can interpret as an inducer of increased international promotion of the river as a tourism destination. As a matter of fact, the Douro 
is being promoted and sold abroad by (at least) 36 foreign private companies, according to a list of international partners provided by Douro Azul, from which we extracted six companies specialising in river cruises that organise specific programmes for the Douro. Our sample will thus include the following operators: Viking, Uniworld, Amawater Ways, All ways Cruises, Noble Caledonia and Vantage. To this group, we add the two fleet owners, Douro Azul and CroisiEurope, as both also act as operators. This choice implies that we left out a considerable portion of smaller retailers and intermediaries that replicate the programme structure of the Douro Azul company. In all, from the eight companies chosen (Douro Azul, CroisiEurope, Viking, Uniworld, Amawater Ways, All ways Cruises, Noble Caledonia and Vantage), 16 programmes on the Douro River for 2015 were analysed (Table 7.6).

Table 7.6 Sample of companies and 2015 programmes analysed

\begin{tabular}{|c|c|c|c|c|c|c|}
\hline $\begin{array}{l}\text { Operator/ } \\
\text { Company }\end{array}$ & Programme & Country & $\begin{array}{l}\text { Boat } \\
\text { Owner }\end{array}$ & $\begin{array}{l}\text { Operates } \\
\text { with Douro } \\
\text { Azul's Boats }\end{array}$ & Days & $\begin{array}{l}\text { Cruise } \\
\text { (days) }\end{array}$ \\
\hline \multirow[t]{3}{*}{ DOURO AZUL } & Invicta & \multirow[t]{3}{*}{ Portugal } & \multirow[t]{3}{*}{ O } & $\mathrm{O}$ & 8 & 8 \\
\hline & Douro Cruiser & & & 0 & 8 & 8 \\
\hline & Spirit of Chartwell & & & O & 8 & 8 \\
\hline \multirow[t]{6}{*}{ CROISIEUROPE } & $\begin{array}{l}\text { Porto et la vallée du } \\
\text { Douro }\end{array}$ & \multirow[t]{6}{*}{ France } & \multirow[t]{6}{*}{ O } & & 6 & 6 \\
\hline & $\begin{array}{l}\text { Porto, la vallée du } \\
\text { Douro et Salamanque }\end{array}$ & & & & 6 & 6 \\
\hline & $\begin{array}{l}\text { Lisbonne et Porto, la } \\
\text { vallée du Douro }\end{array}$ & & & & 8 & 6 \\
\hline & $\begin{array}{l}\text { Le Douro, l'âme } \\
\text { portugaise }\end{array}$ & & & & 8 & 8 \\
\hline & $\begin{array}{l}\text { Croisière randonnée au } \\
\text { Portugal }\end{array}$ & & & & 8 & 8 \\
\hline & $\begin{array}{l}\text { De Porto vers } \\
\text { l'Espagne }\end{array}$ & & & & 8 & 8 \\
\hline $\begin{array}{l}\text { ALL WAYS } \\
\text { CRUISES }\end{array}$ & $\begin{array}{l}\text { Le Douro au départ de } \\
\text { Porto avec Salamanque }\end{array}$ & Belgium & & O & 8 & 8 \\
\hline $\begin{array}{l}\text { NOBLE } \\
\text { CALEDONIA }\end{array}$ & Along the river of Gold & UK & & O & 11 & 6 \\
\hline $\begin{array}{l}\text { AMA } \\
\text { WATERWAYS }\end{array}$ & Enticing Douro & USA & & O & 12 & 8 \\
\hline \multirow[t]{2}{*}{ UNIWORLD } & $\begin{array}{l}\text { Portugal, Spain and the } \\
\text { Douro River Valley }\end{array}$ & USA & & \multirow[t]{2}{*}{ O } & 11 & 8 \\
\hline & $\begin{array}{l}\text { Jewels of Spain, } \\
\text { Portugal and the Douro } \\
\text { River }\end{array}$ & USA & & & 13 & 8 \\
\hline VANTAGE & $\begin{array}{l}\text { Portugal and the Douro } \\
\text { River Wine Country }\end{array}$ & USA & & O & 11 & 8 \\
\hline $\begin{array}{l}\text { VIKING RIVER } \\
\text { CRUISES }\end{array}$ & $\begin{array}{l}\text { Portugal's River of } \\
\text { Gold }\end{array}$ & USA & & O & 10 & 8 \\
\hline
\end{tabular}

Source: Douro Azul; CroisiEurope; All ways Cruises; Noble Caledonia; Amawater Ways; Uniworld; Vantage; Viking River Cruises (2015) 
The analysis of the programmes of the operators ${ }^{3}$ is of particular relevance, as it can be considered as a formal source (Goodall 1990), a formal interpersonal source (Hsiesh and O'Leary 1993), an external formal source (Gitelson and Crompton 1983), a commercial source (Mill and Morrison 1985), an overt induced source (Gartner 1993) and/or a professional source (Baloglu 1997), capable of inducing changes in the destination image and the consumer decision-making process of travellers (Gartner 1993; Gartner and Bachri 1994).

This potential underlies the programmes' utility, such as being a relevant data extraction source in order to calculate the geographical and heritage impact of the Douro River operations in a tourism context, and thus, to enable us to understand the models and patterns constructed by the programme makers in terms of space (where and when) and patrimony. Clarifying, on the one hand, the spatial and geographical complexity of the programmes, and analysing, on the other hand, the resources which can be seen/visited, we will reveal the semiotics that are implicit in the representation and programming of the destination (Coupland 2010; Guedes 2014). In other words, we will disclose the level of compliance between the activities of river cruises in general and the wine-oriented activities in particular, just as we will, by analogy, examine the ability of the programmers to interpret the wine tourism value of the region justly.

To answer to these objectives, we choose two variables: the local resources (physical, non-physical and natural heritage) and the number of overnights scheduled per municipality unit. The number of overnights was converted into an intensity indicator of the programme (where do they go, how often and for how long) by calculating the corrected arithmetic mean of the number of overnights $(\mathrm{ms}=m \times \mathrm{fs} \times 100),{ }^{4}$ taking into account that the number of cases per municipality unit was different, and thus originated incomparable arithmetic means. A punctuation of 0.5 was attributed to all of the municipalities visited as a way of distinguishing them from unscheduled (and thus, not visited or unseen) geographical units (Guedes 2014).

The results were also transposed into maps, thus seeking to demonstrate the complex paradigms of the interdependence of geographical units on the mainland, taking into account their degree of association (Guedes 2014). The graphical projection also aims to recognise the gateways which provide access to the destination, and the variables of the length and the kind of stay in each municipality, identifying cross nodes as hubs and/or stopovers, in order to determine how different scheduled geographical units are linked (Rodrigue et al. 2006).

\subsubsection{Results}

The analysis of the results focuses on two important areas, namely, the geographic content of the programmes and the resources listed.

\footnotetext{
${ }^{3}$ Material received through travel agents and tour operators.

${ }^{4} \mathrm{~m}$ : arithmetic mean; fs: relative frequency.
} 


\subsubsection{Geographic Content of the Programmes}

Examining the cartographic projection of the 16 selected programmes (Fig. 7.2), we could identify recurrent circulation patterns, that is, they are developed in such way that the itinerary for the ships begins in Oporto and Vila Nova de Gaia and goes upstream along the entire navigable trail, at least until they reach the border with Spain. The second part of the cruise coincides with the reversal of this order, always giving priority to the municipalities bordering the river, ending again with an overnight stay at the mouth of the river (Oporto or Vila Nova de Gaia).

Consequently, the route starts at a gateway where the logistics variable is the main determinant of what is going to be undertaken. Direct accessibility of international markets to the destination through an international airport infrastructure, but also the existence of an interface platform with the river, that is, a docking infrastructure for boats up to $79 \mathrm{~m}$ long, are crucial conditioning elements. Therefore, the presence of the Francisco Sá Carneiro airport and the docking infrastructures warrant centrality for Oporto (as well as Vila Nova de Gaia) and turn that metropolis into a direct gateway to the Douro.

Similarly, in the analysed programmes, in some cases, the function of gateway and catcher of international traffic is concentrated in Lisbon, due to its airport infrastructure (Portela Airport), creating an intermediary role with the transfer of these flows by land (by bus) to more peripheral territorial levels of immersion, in this particular case, Oporto/Vila Nova de Gaia, where the Douro cruises officially start. For those who begin their circuit in Lisbon, stops en route to Oporto can before seen, which provides a broader experience as a result of a larger "tourist irrigation" (Cluzeau 1998: 71) of the programme archetype "Douro". This way, cities like Sintra, Óbidos, Nazaré, Coimbra and Aveiro are discovered before reaching the Douro Valley (Fig. 7.2), where the river cruise will start, which is the heart of the tourist experience in Portugal for participants who choose to initiate their journey in the country's capital.

The programme also incorporates urban centres near Oporto, more specifically, Viana do Castelo, Braga and Guimarães, all of which have a rich cultural heritage, the latter even being classified as a UNESCO heritage site. These cities are integrated into programmes lasting more than 10 days, and they are often visited by bus, allowing the visitors to stroll only a few hours in each city.

In the Douro Valley context (Fig. 7.3), the programmes include places with different levels and kinds of heritage concentration, inter alia, Oporto/Vila Nova de Gaia are urban portals with logistical relevance that enable access to the Douro. Further on, there is Entre-os-Rios, in Penafiel, which provides a docking function for ships, as well as access to the restored Benedictine Convent of Alpendurada (eleventh century). The cruise programmes usually incorporate Peso da Régua to ensure another docking point and the possibility of linking the Douro River, by a vertical and transverse axis, to the two most important urban centres in the region, Vila Real and Lamego. Following the river upstream, we encounter the Alijó municipality, which is of paramount logistical importance as a result of the large docking pier located in the Pinhão parish, which guarantees a secure platform for a stop and 


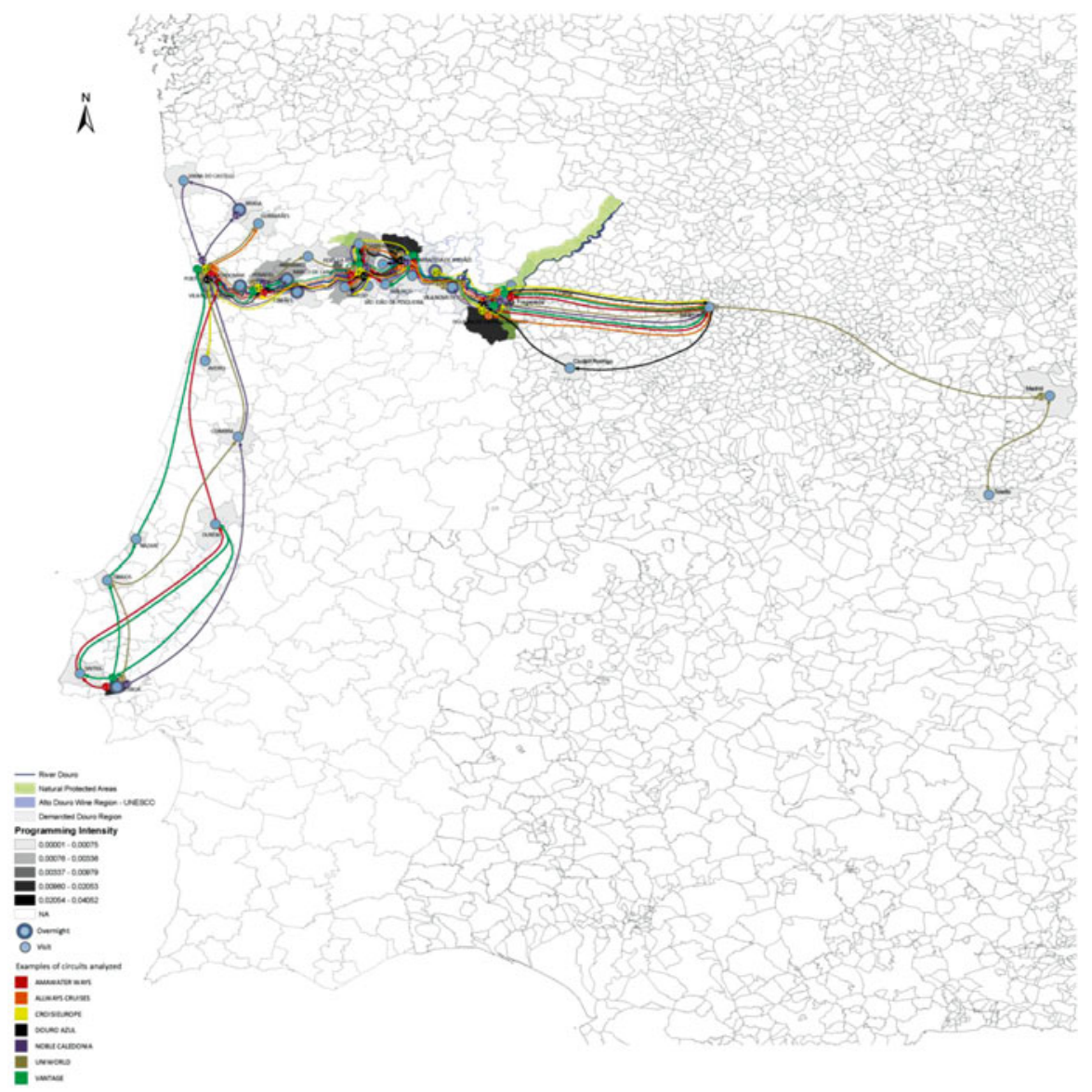

Fig. 7.2 Projection of the circuits described in the programmes. Source: DGT (2014) and CNIG (2015) — map prepared by A. Guedes

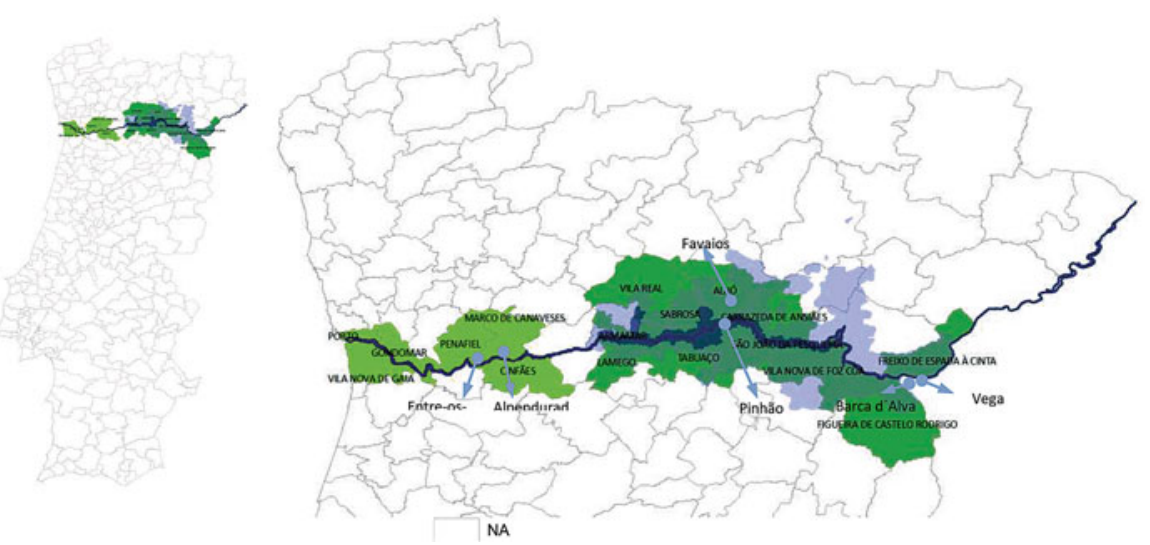

Fig. 7.3 The Douro Valley context in river cruise programming. Source: DGT (2014) and CNIG (2015) — map prepared by A. Guedes 
for leaving the boat, allowing passengers to have a wine tourism experience that is not very distant from the river. Therefore, the passengers are transferred to the left margin of the river, to the Tabuaço municipality, where they can visit a quinta (farm). Back in Alijó, the groups can enjoy cultural experiences, particularly in the Favaios parish.

The upstream itinerary ends in Barca d'Alva, a parish of the Portuguese municipality of Figueira de Castelo Rodrigo, or in Vega Terrón (La Fregueneda), which is on the Spanish side of the river. From Barca d'Alva, the tourist experience is extended in some programmes with a round trip to the historic village of Figueira de Castelo Rodrigo. Note that Barca d'Alva and Vega Terrón are transition and transit units between two sovereign areas (Portugal and Spain), which ensures the extension, by 1 or 2 days, of the schedule in a new cultural context, the autonomous community of Castile and Leon in Spain. The programmers thus succeed in adding a cross-border dimension and an Iberian scale to the Douro. The regional expansion of the programme scope is assured with a connection to Salamanca, which has also been classified by UNESCO, as it represents, similar to Lisbon and Oporto, an interesting and rich urban setting, implying a transmutation of experience: The century-old cities contrast deeply with the age-old nature of the Douro Valley. In one analysed case, the tourist experience is extended by bus to Toledo and Madrid, the latter unit being used as a circuit exit gateway.

\subsubsection{The Heritage Aspects of the Programmes}

With regard to this component, we observe that the programmers best picture and describe the cultural heritage of Lisbon and Oporto. The high polarisation of heritage resources around these two nodes is clearly noticeable in Fig. 7.4. Knowing that these resources are recurring markers that signal a kind of sacred site (Urry 1990), as well as a door to a cultural universe that is more complex, from the point of view of its meaning (...) (Guedes 2014), in Lisbon and Oporto, the accumulation effect of the cultural capital is obvious, with regard to its value, as well as to the concentration of nationally classified assets. These morphologies are two additional examples that illustrate the reasoning of Zukin (1991) regarding the concentration of cultural power in major metropolitan centres (Guedes 2014). Hence, the first wine tourism experience is secured in the Port Wine cellars of Vila Nova Gaia, which occurs only after the tourists have reached the city of Oporto and the group is ready to enter into the Douro Valley.

In most programmes, the Mateus Palace and its gardens in Vila Real are included and are therefore turned into a structural element; the same goes for the Sanctuary of Nossa Senhora dos Remédios in Lamego. Alijó is the third most cited municipality in terms of listed heritage items. There, one can also visit the Quinta da Avessada and its enoteca (an exhibition and degustation space that combines elements of a wine museum and shop), and the vineyard village of Favaios. Likewise, in Alijó, the Bread Museum (Favaios) and the Pinhão railway station's azulejos (historic tiles) are referenced, yet more sporadically. In a third level of referral, Figueira de Castelo 


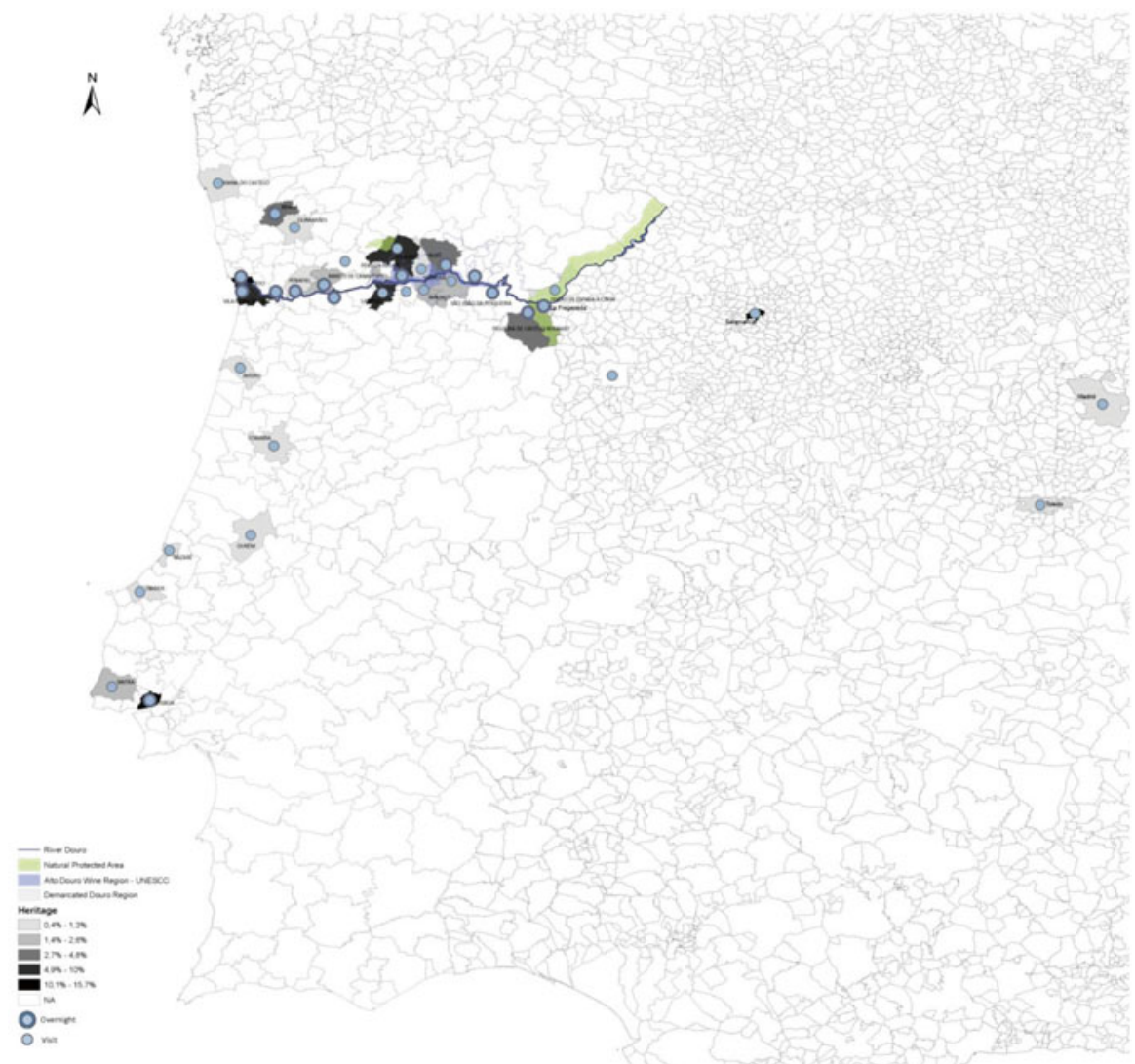

Fig. 7.4 Spatial projection of the identified heritage in the programmes per municipality. Source: DGT (2014) and CNIG (2015) - map prepared by A. Guedes

Rodrigo, famous for its walled medieval village, is visited by cruise goers by bus from the pier in Barca d'Alva.

Although we identified some cases of visits to quintas (farms), their expression tends to be relatively undervalued, compared to the descriptions of natural and cultural heritage, revealing the meagre interaction of the river cruises with the winemaking heritage in the Douro, which is well expressed through the example of the Quinta do Seixo in the Tabuaço municipality: This is the most frequently mentioned farm, with only 6 references out of 16 programmes.

Moreover, our analysis allowed us to find and identify cases of thematic programming, based on natural heritage, including the Alvão Natural Park and the Natural Park of the International Douro, as optional visits. We think that this kind of specialised experience can be disseminated and amplified. 
However, now switching to the museum context, we wonder why there are no references to the Côa Museum. Could this be because of the difficulty of access and articulation with the rest of the programme? These issues do not apply to the Douro Museum in Peso da Régua, which appears to be referenced in some programmes. The insignificant presence of museums, in general, and of these two, in particular, becomes all the more relevant, as both museums are located in areas classified by UNESCO. We would like to underline that the Côa Museum serves as an interpretation space for the Côa Valley Archaeological Park, which safeguards a set of prehistoric rock art sites that were classified by UNESCO in 1998. Moreover, this museum has received, among other awards, an honourable mention from the national entity, Tourism of Portugal, in 2010, in the category "New Public Project", which distinguishes the best tourism projects, and more recently, the Architecture Award Douro 2013/2014.

Returning to urban heritage sites, three centres in the vicinity of Oporto - Braga, Guimarães and Viana do Castelo - are frequently visited by bus. Although the historical centre of Guimarães has been classified by UNESCO since 2001, this city has fewer references than Braga in the analysed programmes, which suggests the importance of religious heritage (strongly present in Braga) in the programming of river cruises against the scant recognition of the value of the heritage that is present in the European Capital of Culture in 2012.

There are cases in which only the name of a municipality is mentioned as a point of interest, without specifying any of the resources present; we can mention the example of Amarante, where no reference whatsoever is made to the sixteenth century Church of São Gonçalo and the bridge over the Tâmega River from the end of the eighteenth century, which are both classified as "National Monuments", and even its art museum, which contains, among other works, paintings of the modernist Amadeo de Souza Cardoso, is simply omitted. There are also excessive examples of inaccurate references: Coimbra, for example, is merely mentioned as having "narrow and picturesque streets"; Lamego is proclaimed to be "the most historic city in the Douro valley"; Vila Real is characterised as a place where "religious architecture is rich" (although the groups only visit the Mateus Palace, far outside of the town centre); and Oporto is solely described, in some programmes, as "one of the oldest cities in Europe." In the case of Aveiro, the inaccurate comparison, "the Venice of Portugal", is intended to unfairly associate the complex and rich heritage of Venice with Aveiro.

In the axis of nodes that serve as a stopover between Lisbon and Oporto, important places comprising assets listed by UNESCO, such as Alcobaça and Batalha, are not included in the programmes, which is odd, given the significance that operators seem to attribute to UNESCO heritage sites. As a matter of fact, a positive association is usually made with UNESCO insignia, as can be illustrated by the following examples, which are evidently included in the programmes: the Historic Centre of Oporto, the Jerónimos Monastery and Belem Tower in Lisbon, the Historic Centre of Guimarães, the Alto Douro Wine Region on the Portuguese side of the Douro, and the Historical Centres of Salamanca and Toledo on the Spanish side of the Duero. 


\subsection{Conclusions}

The analysis of the river cruise programmes for the Douro River allows us to conclude that programmers tend to structure the supply side according to a holistic prototype as they concentrate on taking full advantage of traditional landscaped and/or urban scenarios on the way. Formatting their tour packages, the hotel ship operators exploit the local resources par excellence to persuade possible buyers in international markets to visit the Douro; they thus obviously market and sell the Douro in a truly positive way. One cannot place enough stress on the importance of such private intercession.

Nevertheless, we observe that the programmes under our scope incorporate scarce references to wine (tasting) activities (except in Vila Nova de Gaia) or wineproducing farms; hence, we conclude that the creation and organisation of wineinspired experiences is only a secondary objective. Additionally, the culinary dimension, which may also manifest itself as an important magnifier element for the wine, reveals a residual weight or is even almost non-existent in the 16 analysed programmes.

Although river cruise programmes in the Douro still under-use the wine tourism potential of the region, we anticipate a "spontaneous" adaption of the programme models to the new reality of the Douro supply side, namely, by including more farmhouses having the ability to receive tourists (Rebelo et al. 2013).

It is perceptible that the programme developers know how to add value to the traditional intrinsic resources of the region. However, there are more possibilities to enhance the value of the river cruises on the Douro, particularly inviting other wine regions (Vinho Verde, Távora-Varosa, Dão and Bairrada) to join in. Likewise, it might be a good opportunity to integrate the spa experiences of the nearby Alto Tâmega (Vidago, PedrasSalgadas).

Finally, models and programmatic paradigms that foster new ways of connecting Lisbon and the Douro, while upgrading the level of "tourist irrigation" (Cluzeau 1998: 71) in the interior of the country should be attempted. The following are some examples: crossing the Serra de Estrela heights, the municipalities of Covilhã and Guarda with Jewish influences (Rede de judiarias de Portugal, www.redejudiariasportugal.com) could serve as stopovers, as they might be of particular interest to the Israeli and US markets (Costa 2014); another option is the inclusion of Conímbriga, a rich archaeological city, or Viseu, which is located in the abovementioned Dão wine region, which hosts the important artistic treasures of Grão Vasco, the main representative of sixteenth-century Portuguese painting; and last, but not least, Sao Pedro do Sul, the first spa town in the country.

We would like to emphasise that, in the Douro Valley, the past has been conserved and transformed into a tourism product, from the Neolithic engravings of Côa, to the stunning mountain scenery covered with vineyards, to the mixture of smaller and larger historic towns with rich tangible and intangible heritage, to port artefacts, which the passengers of hotel ships have come to enjoy in increasing numbers.

Other research will confirm whether, in the near future, the percentage of winelinked activities will increase in the programmes of cruise operators for this type of 
river tourism and whether the relationships/networking activities of the owners of these vessels and/or organisers of these cruises, and the entrepreneurs of small and medium local businesses, will intensify and improve. Today, a business model in which the river operators guide large groups in closed circuits by the most beautiful local sites prevails, conditioning the success of the value chain of the activities they propose, virtually by their own presence and participation. New interaction models should be conceived and implemented, so that the passengers on these hotel ships, who have high purchasing power, can spread their wealth more equitably over the places they visit. Other mechanisms must be activated, which can be defined, for example, by listening to and talking with local micro-entrepreneurs in order to stimulate local development in a more balanced way, increasing direct forms of contact between passengers and a larger number of commercial partners.

As a result of the foregoing, there is an obvious and urgent need for the conservation and preservation of the Douro landscape, a necessary and fundamental condition for the diversification of the regional economy, so that, through this, the social fabric can be revitalised and rebalanced; in this process, wine tourism activities should gain importance over the next decade. The more intensely the passengers who travel via the river and overnight on it interact with the stakeholders of the terroir, the greater the benefits for employers, employees and even the unemployed can be, particularly when the full potential of wine tourism, a sector now in full growth, begins to be harnessed. Nautical wine tourism is, indeed, a promising niche market segment for the Douro Valley.

\section{References}

Adams, M. (2006). Nautical wine tourism: A strategic plan to create a nautical wine trail in the Finger Lakes wine tourism region of New York State. In J. Carlsen \& S. Charters (Eds.), Global wine tourism: Research management and marketing (pp. 227-241). Oxon: CAB International.

All Ways Cruises. (2015). Le Douro au départ de Porto avec Salamanque. Retrieved 15 December, 2014, from http://www.all-ways.be/pdf/1758/1758_fr.pdf

Ama Waterways. (2015). Wine Cruises Through Europe: 2015 \& 2016. Retrieved 15 December, 2014, from http://www.amawaterways.com/brochures/2015-2016wine/wine-2015-2016.pdf

Andresen, T., \& Rebelo, J. (2013). Assessment of the state of conservation of the property Alto Douro wine region - Evolutive and living cultural landscape - Assessment report. Porto: CCDRN/EMD \& CIBIO UP/UTAD.

Baloglu, S. (1997). The relationship between destination images and sociodemographic and trip characteristics of international travellers. Journal of Vacations Marketing, 3(3), 221-233.

Cardoso, A. M. de B. (1998). O Douro: Estrada fluvial nos alvoresmo século XVIII. Douro: Estudos \& Documentos, 3(5), 117-132.

Cluzeau, C. (1998). Le tourisme cultural. Paris: Presses Universitaires de France.

CNIG. (2015). Equipamiento Geográfico de Referencia Nacional. Retrieved 17 August, 2014, from http://centrodedescargas.cnig.es/CentroDescargas/equipamiento.do?method=descargarE quipamiento\&codEquip $=3$

Costa, F. (2014). Portugal à conquista do turismo judaico. Expresso, 10 de Fevereiro. Retrieved 27 April, 2014, from http://expresso.sapo.pt/portugal-a-conquista-do-turismo-judaico=f855194

Coupland, N. (2010). The handbook of language and globalization. Chichester, NY: Wiley-Blackwell. 
CroisiEurope. (2015). Le Monde en Croisières. Retrieved 15 December, 2014, from http://www. croisieurope.com/brochures/brochure-individuelle-croisieurope-20142015

INE - Instituto Nacional de Estatística. (2002-2014). Anuário Estatístico da Região Norte: 2001 - 2013. Lisboa: INE.

Del Río Rama, M. C., Álvarez García, J., \& Fraiz Brea, J. A. (2014). Ruta Turística Enológica Rías Baixas (Galicia-España): Análisis desde la Perspectiva de la Oferta. Revista de Cultura y Turismo (Cultur), (01), Febrero, 95-118. Retrieved 17 September, 2014, from http://www.uesc. $\mathrm{br} /$ revistas/culturaeturismo/ano8-edicao1/4.pdf

Del Río Rama, M. C., Álvarez García, J., Vila Alonso, M., \& Iglesias González, L. (2013). Turismo enológico y Ruta del Vino del Bierzo. REDMARKA, year VI, 2(11), 185-212. Retrieved 17 September, 2014, http://www.cienciared.com.ar/ra/usr/39/1502/redmarka_n11_pp185_212. pdf

DGT - Direção-Geral do Território (2014). Carta Administrativa Oficial de Portugal (CAOP). Retrieved 12 January, 2014, from http://www.dgterritorio.pt/cartografia_e_geodesia/cartografia/ carta_administrativa_oficial_de_portugal_caop_/caop_download_

Ditter, J. G. (2005). Reforming the French wine industry: Could clusters work? Cahiers du Ceren, $13,39-54$.

Domingues, Á. (s.d.). O Porto e rio Douro: A construção de uma nova relação. S.1.: Museu do Douro. Retrieved 25 June, 2014, from http://www.museudodouro.pt/exposicao_virtual/pdf/ alvarodomingues.pdf

Douro Azul. (2015). Programas de Cruzeiros em Navio-Hotel. Retrieved 15 December, 2014, from http://www.douroazul.com/Default.aspx?ID=1235

ERTD - Entidade Regional de Turismo do Douro. (2012). Guia turístico do Douro. Vila Real: ERTD.

Gartner, W. C. (1993). Image formation process. In M. Uysal \& D. Fesenmaier (Eds.), Communication and channel systems in tourism marketing (pp. 191-215). New York: Haworth Press.

Gartner, W. C., \& Bachri, T. (1994). Tour operator's role in the tourism distribution system: An Indonesian case study. Journal of International Consumer Marketing, 6(3/4), 161-179.

Gitelson, R., \& Crompton, J. (1983). The planning horizons and sources of information used by pleasure vacationers. Journal of Travel Research, 23(3), 2-7.

Goodall, B. (1990). How tourists choose their holidays: An analytical framework. In B. Goodall \& G. Ashworth (Eds.), Marketing in the tourism industry: The promotion of destination regions (pp. 1-17). London: Routledge.

Guedes, A. (2014). O domínio cultural no turismo organizado - O Caso Português: Da polarização territorial à valorização endógena e local. Salamanca: USAL.

Hsiesh, S., \& O'Leary, J. (1993). Communication channels to segment pleasure travellers. In M. Uysal \& D. Fesenmaier (Eds.), Communication and channel systems in tourism marketing (pp. 57-75). New York: Haworth Press.

IPTM - Instituto Portuário e dos Transportes Marítimos. (2013). Estatística da Via navegável do Douro (VND). Retrieved 12 April, 2014, from http://www.douro.iptm.pt/_admin/upload/ estatisticas/7/8044952_file01.pdf

IPTM - Instituto Portuário e dos Transportes Marítimos. (2014). Douro. Waterway. Introduction. IPTM - North and Douro Delegation. Retrieved 12 March, 2014, from http://www.douro.iptm. pt/EN/via_navegavel/index.aspx

Mill, R., \& Morrison, A. (1985). The tourism system: An introductory text. Upper Saddle River, NJ: Prentice-Hall.

Noble Caledonia. (2015). Along the river of gold. Retrieved 15 December, 2014, from http://www. noble-caledonia.co.uk/brochure/Along_the_River_of_Gold_-_Douro_Prince_-_6pp.pdf

Rastoin, J. L., \& Vissac-Charles, V. (1999). Le groupe stratégique des entreprises de terroir. Revue Internationale PME, 12, 171-192.

Rebelo, J., Caldas, J. V., \& Guedes, A. (2014). The Douro region: Wine and tourism. In B. Bálo, P. Majer, \& G. Váradi (Eds.), Proceedings Xth International Terroir Congress 2014 (Vol. 1, pp. 225-232). Tokaj-Eger: Corvinus University of Budapest. 
Rebelo, J., Guedes, A., Lourenço-Gomes, L., \& Sequeira, T. (2013). Balanço de concretização do programa de ação. In Avaliação do estudo de conservação do bem alto Douro Vinhateiro Paisagem cultural evolutiva e viva, volume 2 - Estudos de base. Porto: CIBIO UP/UTAD.

Rede de judiarias de Portugal. (2015). Rede de Judiarias de Portugal. Retrieved 20 October, 2014, from http://www.redejudiariasportugal.com/index.php/pt

Rodrigue, J., Comtois, C., \& Slack, B. (2006). The geography of transport systems. London: Routledge.

Turismo de Portugal. (2009). O turismo em 2008. Lisboa: Turismo de Portugal.

Uniworld. (2015). Europe \& Russia - Boutique River Cruises. Retrieved 15 December, 2014, from http://static.uniworld.com/media/us-english/7/1/2014/europe-2015-us.pdf

Urry, J. (1990). The tourist gaze. London: Sage Publications.

Vantage. (2015). Portugal and the Douro River Wine Country. Retrieved 15 December, 2014, from https://www.vantagetravel.com/ourjourneys/deluxe-river-journeys/2015/portugal-the-douro-riverwine-country/itinerary

Viking River Cruises. (2015). Portugal's River of Gold. Retrieved 15 December, 2014, from http:// www.vikingrivercruises.com/cruise-destinations/europe/portugals-river-gold/2015-portopinhao-porto/index.html

Zukin, S. (1991). Landscapes of power: From Detroit to Disney World. Berkeley, CA: University of California Press. 